DOI 10.31509/2658-607x-2020-3-3-1-45

\title{
DRAFT BILL CONCEPT OF THE FEDERAL LAW «FOREST CODE OF THE RUSSIAN FEDERATION»
}

\author{
(C) 2020 \\ Gagarin Yu.N. ${ }^{1}$ \\ ${ }^{1}$ Center for Forest Ecology and Productivity of the Russian Academy of Sciences \\ Profsoyuznaya st. 84/32 bldg. 14, Moscow, 117997, Russia \\ *E-mail: j.gagarin@list.ru \\ Received 01.06.2020 \\ Accepted 05.08.2020
}

This paper presents a draft bill concept of the Federal Law "Forest Code of the Russian Federation", which proposes some new approaches to public forest management improvement. The related questions had been discussed during scientific debates held by the Scientific Council of the Russian Academy of Sciences on forests in 2015-2019. The goal of the draft bill concept is to modernise the forest law of the Russian Federation to bring it in line with changes in the state of forests, their increasing role in climate regulation and other ecosystem services, as well as the further development of market relations in the Russian economy. The Concept Paper is based on an idea of a transition from the use of natural forests as a source of timber to the organisation of economic activities aimed at the cultivation of highly productive forest stands on available forest land, and on understanding of importance of natural forests for conservation of biodiversity and ecological ecosystem services. Suggestions aimed at developing economic mechanisms to ensure forestry profitability in a market economy, both through forest products and ecosystem services, make up an important part of the Concept Paper. Approaches to the further development of public and private forest management, which will improve the efficiency of forest use, protection, conservation and regeneration, are outlined. Legal mechanisms for improving the public forest management system and forms of state and business participation in forest management are proposed.

Key words: forest fund, forestry, public forest management, private forest management, ecosystem services

\section{Introduction}

Based on the analysis of change in resource potential and ecological state of forests over time, and taking into account the growing needs of the society for forests forest resources and services, each country creates forest laws aimed at ensuring a balance between economic, environmental and social aspects of forestry development and forest conservation for present and future generations.
The need for coherent forest laws based on the priority of state ownership of forests and implementing the basic principles of sustainable forest management, on the one hand, stems from the long-life cycle of forest ecosystems, reaching decades and centuries, and on the other hand results from global challenges to which humanity must respond effectively, conserving forests and maintaining a balance between forest ecosystem services at the same time. 
It is this approach to the further development of forestry and forest relations that has become the starting point for formulating provisions that form the basis of the draft bill concept of the Federal Law "Forest Code of the Russian Federation", drafted by the working group of the Scientific Council of the Russian Academy of Sciences on forests (hereinafter - the Council) and presented in this article by Yuri N. Gagarin, member of the Bureau of the Council, head of the forest policy cluster and lead researcher at CEPF RAS.

This paper outlines approaches to improving public forest management that had been developed during the discussions of the main problems of forestry in Russia at the scientific debates held by the Council in 2015 to 2019. The problems of law making and law enforcement in the sphere of forest relations were analysed and approaches for the further development of public and private forest management were outlined, the implementation of which will make it possible to increase the efficiency of forest use, protection, conservation and regeneration.

The Concept Paper is based on an idea of a transition from the use of natural forests as a source of timber to the organisation of economic activities aimed at the cultivation of highly productive forest stands on available forest land, and on understanding of importance of natural forests for conservation of biodiversity and ecological ecosystem services. Suggestions aimed at developing economic mechanisms to ensure forestry profitability in a market economy, both through forest products and ecosystem services, make up an important part of the Concept Paper.

The proposals underlying the concept of the draft «Forest Code of the Russian Federation» have been considered by an extended meeting of the Council and are recommended for use by government agencies in the interests of the Russian Federation. 


\section{TABLE OF CONTENTS}

1. General idea, objectives and subject of legal regulation .5

2. General overview and assessment of the state of legal regulation regarding forest relations.....7

3. Fundamental provisions of the draft bill ......................................................................... 11

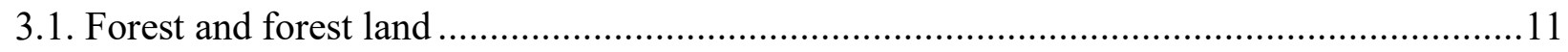

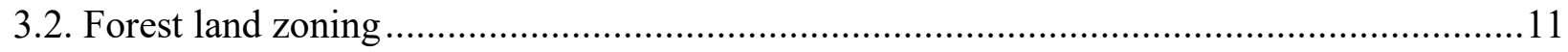

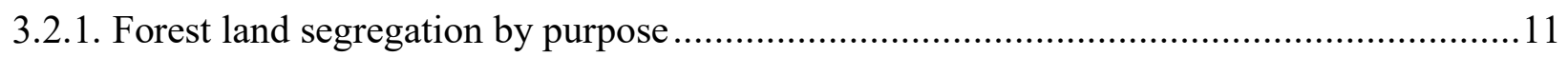

3.2.2. Zoning of operational forests by forest use intensity.............................. 12

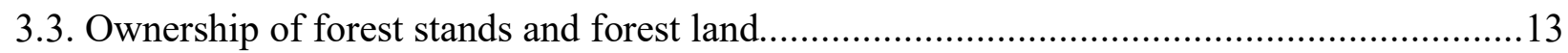

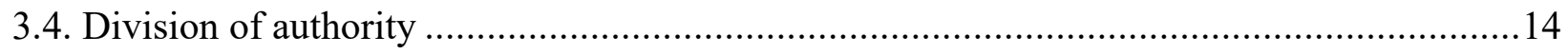

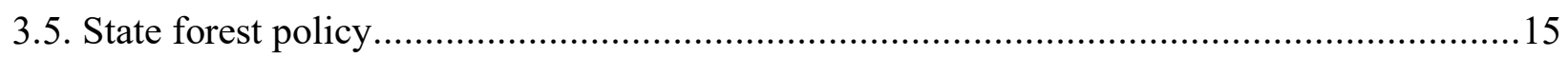

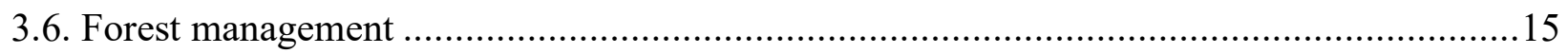

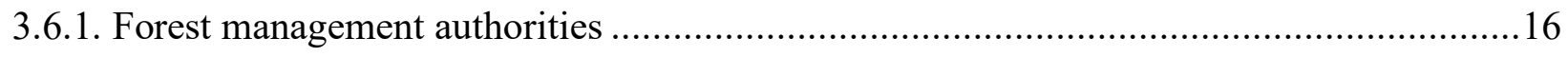

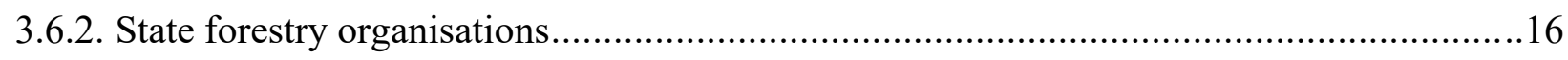

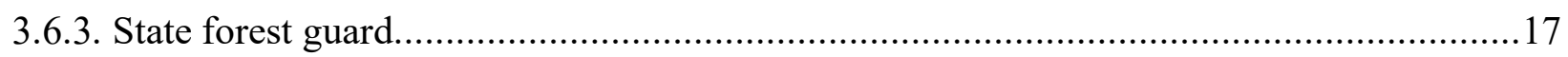

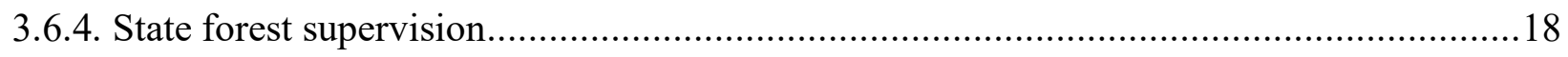

3.6.5. Permanent (termless) use of forests...................................................................... 18

3.6.6. Private (non-governmental) forest management ................................................... 18

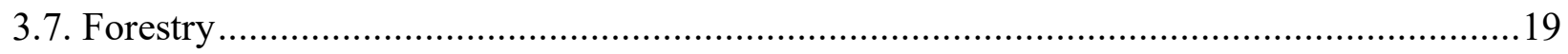

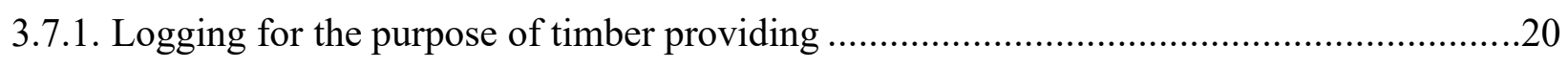

3.7.2. Meeting the need of the forest industries for timber ...............................................22

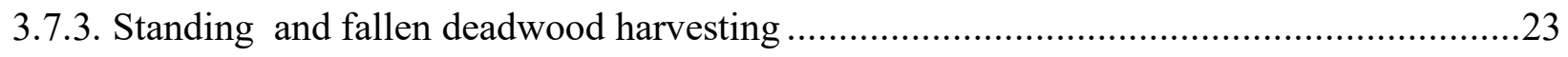

3.7.4. Commercial harvesting and collection of non-wood forest products .............................24

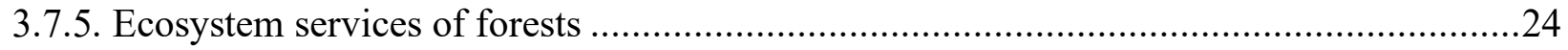

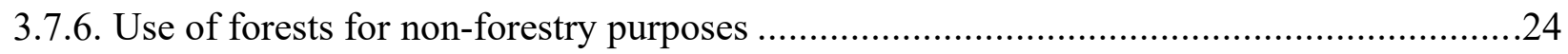


3.7.7. Protection and conservation of forests .25

3.7.8. Conservation of forest biological diversity and genetic resources .26

3.7.9. Selection seed breeding and harvesting of forest tree seeds..... .27

3.7.10. Reforestation 27

3.7.11. Thinning. .29

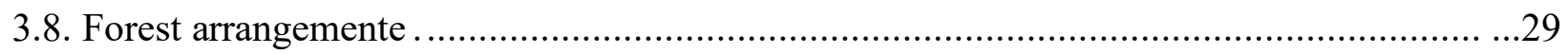

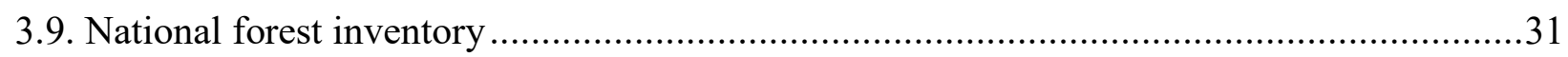

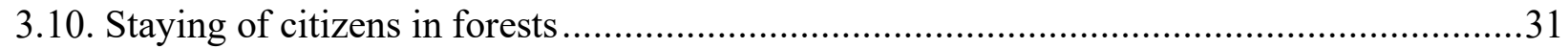

3.11. Capital construction and temporary facilities in forests ........................................... 32

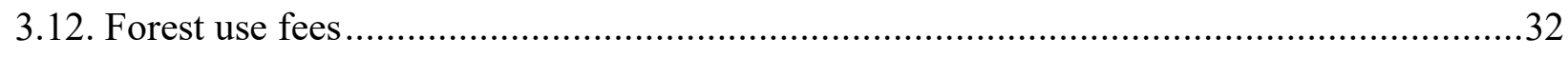

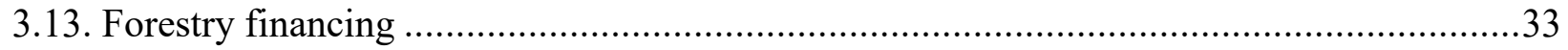

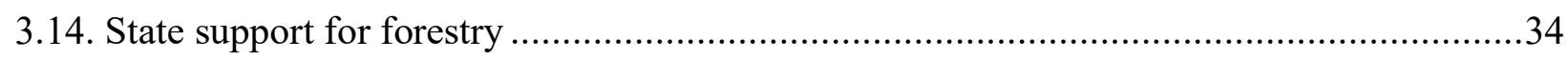

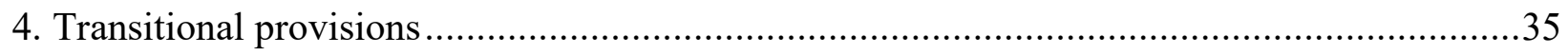

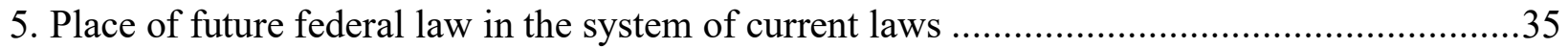




\section{General idea, objectives and subject of legal regulation}

The draft bill concept of the federal law "Forest Code of the Russian Federation" (hereinafter - the Concept Paper) is based on an understanding of a limited area of economically accessible forests and their declining quality and productivity, as well as on the results of assessment of the state and efficiency of forest management, which create the necessity to improve the legal regulation of forest relations.

The Concept Paper is based on an idea of transition from the use of forests as a source of timber to the organisation of economic activities aimed at the cultivation of highly productive forest stands on available forest land. It proposes to build an institutional environment in which forestry will meet the needs of the society for forests and forest resources at the expense of its own income.

The goal of the Concept paper is to ensure comprehensive modernisation of forest laws of the Russian Federation to bring it in line with changes in the state of forests, their increasing role in climate regulation and other ecosystem services, as well as the further development of market relations in the Russian economy.

The Concept Paper establishes obligations of the state and society in relation to forests and introduces environmental (nature protection oriented) restrictions on forestry operations, ensuring the preservation of favourable environment for people and the functioning of natural ecosystems.

Provisions of the Concept Paper provide for the reduction of the mandatory legal regulation of forest management issues in favour of nonbinding recommendatory norms based on scientific progress and world practice of forest management.

At the same time, legal mechanisms for improving the public forest management system and forms of state and business participation in forest management are proposed.

Implementation of the Concept Paper will increase the general level and efficiency of the legal regulation of forest relations through:

(a) establishing state ownership of forests and forest resources;

(b) joint management of issues related to ownership, use and disposal of state-owned forests by the Russian Federation and the constituent entities of the Russian Federation;

(c) division of powers and jurisdictions in forest relations between the agencies of state power of the Russian Federation and the agencies of state power of the constituent entities of the Russian Federation, inventory of state functions and services to be performed by each authority;

(d) defining the legal framework for sustainable forest management, its goals and objectives, as well as its principles of organisation;

(e) establishment of responsible parties to perform state duties and services in forestry at regional and federal levels.

Relevance and timeliness of the forest law updates result from:

- understanding the importance of forests in providing global ecosystem services, increased consumption of forest products and increased competition in global timber markets;

- inefficient legal regulation of forest relations due to the imbalance of forest laws aggravated by numerous and multidirectional 
changes made to the «Forest Code of the Russian Federation» in recent years, which led to the reduction of forest area and the depletion of its resource potential.

The nature and speed of processes that have a negative impact on the state of forests make it necessary to radically revise the main body of sectoral legislative norms and to create new ones which are able to tackle the challenges and meet the needs of the society for a variety of forest products and services.

The Concept Paper will contribute to the comprehensive modernisation of the forest laws of the Russian Federation, aimed at tackling the following main tasks:

- ensuring sustainable forest management at local, regional and federal levels;

- conservation and enhancement of the social, environmental and economic potential of forests;

- defining the rights, duties and responsibilities of all parties to forest-focused legal relations;

- achieving a balance of interests of the parties to forest-focused relations at the federal, regional and municipal levels, including the indigenous (local) population;

- development of financial and economic mechanisms for forestry based on the correlation of its income and costs, which will guarantee the conservation of forests and increase their resource potential;

- informational, personnel and scientific support of forest management.

The subjects of the legal regulation of the Concept Paper are forest (economic and public) relations associated with the use of forests to meet the needs of the society for forests and forest resources, including relations arising during implementation of constitutional principles on subjects of joint management of the Russian Federation and the constituent entities of the Russian Federation, as well as property relations on the ownership, use and management of forests.

Individuals and legal entities covered by the draft bill. Citizens of the Russian Federation, agencies of state power of the Russian Federation, agencies of state power of the constituent entities of the Russian Federation, local authorities, state forestry organisations, as well as individuals and legal entities involved in forest management and use will be subject to the provisions of the proposed draft bill of the federal law.

The Concept Paper provides for the establishment of new rights and obligations of the subjects of forest relations arising from the necessity of:

- the decentralisation of public forest management, including the powers of regulation of forest relations;

- separating the performance of legislative, regulatory and control functions by state authorities of the Russian Federation and state authorities of the constituent entities of the Russian Federation;

- creating a market for forest ecosystem services,

- development of economic relations in forestry, the transition of forestry activities from the sphere of state-financed services to the profitable sector that provides the society with forest products and services;

- the development of private forest management tools;

- the inclusion in forest fund of abandoned agricultural lands that are overgrown with forest; 
- addressing multiple gaps and contradictions in existing law.

\section{General overview and assessment of the state of legal regulation regarding forest relations}

Forest relations are currently regulated at the federal level by the Constitution of the Russian Federation, the «Forest Code of the Russian Federation», land and water laws, the Code of Administrative Offences, as well as other statutes that address certain issues of forest development.

Forest relations are also regulated by numerous laws and regulations of the Government of the Russian Federation, the Ministry of Natural Resources of Russia and the Federal Forestry Agency, the adoption of which is provided for in the «Forest Code of the Russian Federation». At the regional level, forest relations are regulated by laws and regulations of the constituent entities of the Russian Federation.

The adoption of the «Forest Code of the Russian Federation» in 2006 contributed to the formation of new forest relations applicable to market economy conditions and private forest management. The Forest Code excluded the simultaneous implementation of forestry activities in the forest areas by both state and private enterprises, which have significantly increased the business responsibility for the condition, reproduction, protection and conservation of forests. Today, under the current forest laws, lessees of forest areas perform more than $80 \%$ of the total volume of forestry activity, contributing to the model of private economic management of operational forests.

However, the 2006 Forest Code did not become a basis of an ordered and balanced system of forest management. The adopted forest management model, which was based on lease relations, proved to be unacceptable in practice due to lessees' lack of interest in forest management results, except for the minimisation of losses from penalties imposed for non-compliance with contractual terms. Obviously, this is an inherent problem caused by the nature of the lease relations and features of forestry designed to meet the needs of current and future generations for forests and forest resources.

Lease relations resulted in the deterioration of forest state and in reduced economic and environmental forest potential. Attempts to establish the total control of forest lease agreement implementation did not lead to the desired result. Moreover, constant monitoring of the lessees' performance of the activities designated by the forest management project has led to increased costs of public forest management, which are now comparable to the costs directly related to forestry itself.

Studying foreign experience in building national forest management systems shows that forest lease has not been widely applied in international practice.

The current Forest Code has contributed to the overexploitation of economically accessible forests, thus reducing their productivity. At present, the share of mature and overmature coniferous tree stands of high productivity (site classes 1-3) does not exceed $16 \%$, and the actual productivity of pine and spruce tree stands is 35 to $53 \%$ of their potential productivity. The deterioration of the state of forests and the decrease in their productivity was due to the logging of the most accessible and high-quality forests in an amount exceeding the limits of sustainable forest use, which is why sawmills that require high-quality (suitable for sawing) wood are 
already being closed down in a number of regions.

Violation of the principles of sustainable forest management was due to a few provisions of the forest laws that exclude state participation in the forest management planning and design and in the assessment of forest stands designated for logging. According to experts and specialists of the industry, the existing lease relations allow to cut down forest stands in an amount significantly exceeding (as estimated, by 40 45 million cubic meters) the contractual terms. Obviously, this process is driven by not burdened with responsibility tenant's motivation to increase profits.

The gaps in the current forest laws include issues related to ensuring the reproduction of forests, which is currently ensured mainly by natural regeneration (over $80 \%$ ). Such forest regeneration leads to coniferous and hardwood broadleaved species being increasingly replaced with forests dominated by aspen, birch and grey alder.

In addition, the lack of provisions in the current forest laws aimed at preserving the results of artificial reforestation until forest stands have acquired resilience in competition with coppice regeneration resulted in a low efficiency of artificial reforestation. According to the results of an expert assessment conducted by public nature protection and scientific organizations in 2017-2019, the survival of planted forests did not exceed $35-40 \%$.

Forests that are not leased are also in a challenging situation. The original idea of the legislator, which envisaged the involvement of the entire forest area into the economic turnover, was not implemented due to the economic inaccessibility of most of the forests and because of the existence of restrictions preventing their economic development. As a result, more than $70 \%$ of forests were unmanaged, and the state forest guard was as good as annihilated. Despite changes in forest laws (2014) that allow constituent entities of the Russian Federation to establish state budgetary and autonomous institutions ensuring the protection and reproduction of non-leased forests, the quality of forest management has not improved. This is mainly because the legislator has not stated the sources of funding for those institutions.

Since 2008, there has been a deterioration in forest fire safety, with the average annual forest area exposed to fires in the Russian Federation exceeding 6 million ha. Despite the measures taken, including those of a legislative nature, there is no expected reduction in the areas of forests exposed to fires. Laws and regulations provided for by the Forest Code could not solve the problems of early detection and extinguishing fires in the forest; therefore, the fight against forest fires has come down to the elimination of constantly occurring emergency situations, which are beyond the competence of forestry.

One of the innovations of the Forest Code of 2006 was the extension of the land law to forest relations. In this regard, the legal status of forest land plots and quarters, defined as land plots, led to a number of excessive organisational actions, which, as practice has shown, caused an unjustified increase in costs associated with the need to form a forest (land) plot and to carry out its cadastral registration and the registration of property rights.

The need for these actions was due to the expected application of the forest lease right as an economic instrument that would 
increase the capitalisation of forest users. However, practice has shown that credit institutions have not accepted such an instrument as a pledged collateral, which is due both to the uncertainty of the lease object (a forest to be felled cannot be an object of lease) and the high risks of forest conservation. Therefore, further application of land law provisions in forest relations does not seem beneficial. Land plots shall be formed solely for the purposes of establishing the boundaries of forests, the transfer of land plots from one category to another and the establishment of the servitude regarding forests used for purposes unrelated to forestry.

Analysis of the application of norms of the civil laws in forest relations (when organising forest management) shows that their implementation has also led to a significant and unreasonable increase in the costs for forest users involved in timber harvesting. For example, according to Art. 71 of the «Forest Code of the Russian Federation», the forest area lease agreement today is subject to the general provisions on lease stipulated by the Civil Code of the Russian Federation, according to which the lessee is obliged to properly maintain the leased property and to bear its maintenance costs. Therefore, the lessee of a forest plot who pays for felling forest stands also has to bear an additional responsibility for ensuring the conservation of forests and their reproduction. This approach obviously has no economic basis and is preserved and supported mainly by minimising the amount of forestry activities in the leased forest area or their formal performance. This ultimately leads to a reduced potential of exploited forests.

Another problem with modern forest laws is the uncertainty and inconsistency of its norms. For example, the provisions of the Forest Code of 2006 do not clearly define the subject of the lease agreement, the forest plot itself or the right to harvest certain forest resources on its territory. This results in significant problems in the organisation of the multi-purpose use of forests, which does not allow to distinguish between the rights and responsibilities of people using the same forest plot for different purposes.

Moreover, several provisions of the current Forest Code do not correspond to the Civil Code of the Russian Federation. For instance, the requirements of the Civil Code of the Russian Federation obliging the lessee to return the land plot upon expiry of the lease term in the condition in which it was obtained are not implemented in the forest laws. The absence of corresponding provisions is due to the impossibility to preserve the exploited forest area, because logging is the lessee's task and receiving monetary compensation for logging is the owner's goal.

The analysis of the practice of applying forest stand purchase/sale agreements in the organisation of forest use showed that the extension of the civil law on the agreement to forest relations increased bureaucratic procedures, the amount of which, by its complexity, exceeds the actions previously associated with obtaining logging permits. This has significantly limited the access of local people to forest resources and contributed to increased illegal forest use.

Experts have repeatedly highlighted the imperfections of the current forest laws in terms of the division of powers and jurisdictions between the agencies of state power of the Russian Federation and the agencies of state power of the constituent 
entities of the Russian Federation on forest management.

In accordance with the Constitution of the Russian Federation, ownership, use and disposal of natural resources are under the joint jurisdiction of the Russian Federation and the constituent entities of the Russian Federation. To implement this principle of federalism while preserving federal ownership of forests, forest laws provide for the federal centre to transfer its authority to manage forests to the constituent entities of the Russian Federation. However, although powers seem to be divided, this model still has all signs of the centralised administrative management: federal executive agencies retained almost all functions in planning, management, coordination and control over forest management (Art. 83 of the «Forest Code of the Russian Federation»).

In this regard, more than a decade of law enforcement practice has shown that the federal centre and regional authorities have developed significant differences in their ideas of practical ways of joint forest management, which has created a number of conflict situations resulting in economic and environmental losses. Most industry specialists believe that the establishment of such "duality of power" has become one of the main reasons for the decreased efficiency of the forest sector.

Another important problem limiting the development of forestry is the imperfect legal regulation of the use of land overgrown with forest vegetation. According to various estimates, the Russian Federation has 40-60 million ha of forests located on agricultural and undistributed lands, naturally formed in the absence of economic activity. Most of the lands overgrown with forest vegetation cannot be returned to agricultural turnover due to a broad range of natural and socio-economic reasons, i.e. low productivity of lands, the small size of plots, making the use of modern highly productive equipment impossible, exposure to intensive water or wind erosion, unfavourable climatic conditions, a lack of labour resources.

The optimum solution to this problem is to use the lands for forest management, which will ensure annual production of more than 300 million cubic meters of high-quality timber in areas adjacent to public road networks, in addition to the creation of 100.000 permanent jobs in rural areas. The viability of such an approach is confirmed by the modern experience of most countries of the temperate zone of the northern hemisphere, where the worst and disused agricultural lands have been intensively involved in various forms of forestry over the last 2 to three decades.

The system of legal regulation of forest economy issues must be optimised. Current forest and budget laws have no economic incentives for effective forest management. Forestry remains the only production industry that has no legally recognised products and services and is financed exclusively from the national budget, therefore placing forestry among consumers of budget funds along with culture, medicine and education.

The existing challenges hindering effective forest management are, to a large extent, caused by the lack of economic mechanisms in the relations between the state and forest users, which are inherent when enterprises carry out economic management of property not owned by them. In the absence of such economic mechanisms, the amount of lease 
payments does not depend on the amount of forestry works carried out by the lessee as well as the expenses related to their implementation. This leads to a decreased intensity of forestry and provides numerous opportunities for corruption.

The above is not an exhaustive analysis of the reasons for the ineffectiveness of the modern forest laws. Despite several amendments to the 2006 Forest Code, this fundamental document still contains significant gaps and shortcomings, and a number of its provisions remain declarative and contain norms that do not have effective mechanisms of implementation. All this creates significant difficulties in the law enforcement process and indicates that introducing changes to the current forest laws has already reached its limits.

Therefore, the development of the new «Forest Code of the Russian Federation» is timely and relevant. Improvement of the legal regulation of forest relations to improve the efficiency of public forest management, the formation of economic forestry mechanisms that exclude excessive state regulation and create conditions for private forestry, will increase the potential of Russian forests and ensure their rational and sustainable use in the interests of current and future generations.

\section{Fundamental provisions of the draft bill} 3.1. Forest and forest lands

The definition of forest in the Concept Paper is in line with the ideas of V.N. Sukachev about forest biogeocenosis. A forest is considered as an integral system of interacting plants, animals, micro-organisms, soil and other components of the environment that are interconnected and influence each other in their development.
Forests include land with an area of more than 0.5 ha, where trees over 5 meters high, forming a canopy with more than $10 \%$ closure, or trees that can reach these thresholds on a given plot, grow or can grow.

Forests also include areas temporarily deforested due to clear cutting or natural disasters, which are expected to be reforested within 5 years, as well as forest roads, fire breaks, nurseries and other forest infrastructure in the area. Forests do not include fruit plantations in agricultural production systems and urban land-use plantations, except urban forests.

Lands occupied by forests which are in state ownership belong to the forest fund. The Concept Paper designates as forest fund the land intended for forest conservation, which can be transferred by the owner to another type of land use solely for national or municipal needs. The forest fund may include both forest and non-forest land.

The forest fund may also include lands occupied by woody and shrub vegetation (a community of perennial plants above $0.5 \mathrm{~m}$ and below $5 \mathrm{~m}$ in height when mature), water and wetlands.

\subsection{Forest land zoning}

3.2.1. Forest land segregation by purpose

According to the Concept Paper, forests are allocated to their designated purpose as follows:

- forests of specially protected natural

areas (hereinafter referred to as protected areas, or PAs);

- protective forests;

- operational forests;

- wilderness forests (unmanaged forests).

Forests of protected areas include those located on the territories of state nature reserves, national parks, natural parks, natural 
monuments, sanctuaries and other protected areas of federal, regional or local significance established by federal laws.

Forests shall be classified as protected areas when they are established by the authorised federal executive agencies (protected areas of federal significance) or by the authorised executive body of the constituent entity of the Russian Federation (protected areas of regional significance). The decision to establish a protected area is at the same time a decision to transfer forests from operational forests to protected area forests.

The use of forests located on the lands of protected areas shall be carried out in accordance with the requirements of the laws on protected areas.

Forests in protected areas shall not allow the use of forests that can lead to the degradation or loss of valuable natural objects, for the conservation of which they are established, as well as other uses of forests if they are prohibited by the mode of protected areas.

Protective forests include forests whose main management objective is to create a favourable environment, protect water bodies and soil, as well as to protect natural, economic and social objects and valuable forests. Within protective forests, there are different categories depending on the features (acceptability) of their use.

The Concept Paper distinguishes between public forests, i.e. forest and parkland zones, and urban forests. It is not allowed to provide forests in forest and parkland zones and urban forests for use by individual legal entities or individuals.

Operational forests are those whose primary management objective is to achieve a multi-purpose, balanced use aimed at obtaining high-quality wood as efficiently as possible, as well as non-wood forest products, while maintaining a balance between the ecosystem services of forests. Protected forest areas are distinguished within the operational forests.

\subsubsection{Zoning of operational forests by forest use intensity}

The Concept Paper proposes the zoning of operational forests by levels of intensity of forest management, applied forest management methods and forms of their provision for use. Such zoning is performed depending on the state of forests, the demand for forest resources, the availability of transport, industrial and social infrastructure in the region, as well as on the financial situation and availability of funds for forestry in the constituent entity of the Russian Federation.

Zones of intensive forestry and extensive forest use are distinguished within the operational forests.

The draft bill concept refers to intensive forestry as an economic activity characterised by the mobilisation of a significant amount of financial, physical and human resources to continuously meet the needs of the economy and society for wood of target species within the areas with a well-developed transport system. The permitted felling volume in intensive forestry zones shall be established considering the efficiency of this economy as well as the achieved and projected terms of the reproduction of economically valuable forests.

It is expected that in zones of extensive forest use, forests will be used periodically (temporarily); their subsequent regeneration is mainly due to the natural reproduction capacity of forests. The permitted felling 
volume in zones of extensive forest use shall be established considering the time of the natural reproduction of economically valuable forests as well as the losses due to fires, outbreaks of pests and diseases and other similar processes and phenomena.

Moreover, forests are divided into zones where forestry is managed by state forest management organisations and into zones where forestry is transferred to private enterprises.

Decisions to establish boundaries of intensive forestry zones and zones of extensive forest use as well as areas with nonstate forms of forest management within the operational forests shall be made by the agencies of state power of the constituent entities of the Russian Federation based on the criteria established by the Government of the Russian Federation.

Wilderness forests include forests that are inaccessible for economic use because they are too far from industrial and social infrastructures (former reserve forests); they also include intact forest areas with high conservation value. There are no activities related to use of wilderness forests.

The Concept Paper regards establishing boundaries of protective forests and criteria and standards for determining categories of protective forests and specially protected forest areas, as well as legal regimes of these forests and forest areas as areas falling within the powers of the Russian Federation. It also establishes that changes in the boundaries of protective forests and protected areas forests, which may lead to a decrease in their area, are not allowed.

In accordance with the Concept Paper, the establishment of boundaries of operational forests and wilderness forests is within the powers of the constituent entities of the
Russian Federation, since changes in the socio-economic development of the region can be considered at this level of management.

\subsection{Ownership of forest stands and forest lands}

According to the Concept Paper, the forests located within the forest fund are owned by the state. The draft bill does not provide for the division of state ownership of forests between constituent entities of the Russian Federation and the federal centre. This approach does not diminish the legal status of the forest fund as a public asset. At the same time, it allows to implement the federal principles of state structure in matters of forest management and use, as well as to avoid the duality of forest management through the territorial distribution of forest management authorities between different levels of government.

In addition to state ownership of forests, the draft bill provides for the private ownership of forests in accordance with Article 9 of the Constitution of the Russian Federation. In accordance with the Concept Paper, land plots from exploitable forests for timber production (forest growth) may be provided for private ownership.

To conduct forestry, the Concept Paper proposes the provision of land plots from the forest fund for the permanent (termless) use to state forestry organisations established by executive agencies of a constituent entity of the Russian Federation.

To conduct forestry in protective forests, individuals and legal entities may receive forest areas for trust management. 


\subsection{Division of authority}

The Concept Paper provides for the comprehensive implementation of the Constitution of the Russian Federation (Article 72), establishing the joint jurisdiction of the Russian Federation and the constituent entities of the Russian Federation over matters of possession, use and disposal of natural resources. Its basic provisions provide for the division of the subjects of jurisdiction and authorities for the possession, use and disposal of state forests between federal agencies of state power and agencies of state power of the constituent entities of the Russian Federation on a territorial basis.

The proposed law classifies forest ownership issues as joint jurisdiction of the Russian Federation and the constituent entities of the Russian Federation and distributes the functions of disposal and the use of forests in accordance with their intended purpose:

- in forests of protected areas of regional significance, protective and operational forests - to the constituent entities of the Russian Federation;

- in forests of protected areas of federal significance and wilderness forests - to the Russian Federation.

The Concept Paper identifies the following matters of joint jurisdiction of forest relations between the Russian Federation and the constituent entities of the Russian Federation:

- development of public policy in relation to forests;

- development and adoption of forest laws ensuring the implementation of constitutional rights and freedoms of citizens, defining general principles of forest management and use;
- implementation of state support measures for forestry, which implies financial support for long-term functions and services of forests, primarily aimed at meeting the need for forests of future generations;

- forest science and education.

The Concept Paper assigns as direct powers to the constituent entities of the Russian Federation the management of protective and operational forests, including the generation of income from such management. This approach involves a shift from the existing functional delegation of authority to a territorial distribution of authority that differentiates forests by management level depending on their purpose.

It is proposed that the federal authority in the field of management of protective and operational forests shall include aviation protection (detection and extinguishing of forest fires using aviation forces and means) of remote operational and protective forests adjacent to wilderness forests, as well as taking state forest inventories.

The draft bill proposes the decentralisation of legislative and regulatory powers in the sphere of forest relations as follows:

the federal centre shall be empowered to establish general principles of sustainable forest management, conservation of biological diversity of forests, their environment forming and protective functions, as well as principles of the formation of state and nonstate forest management systems.

According to the Concept Paper, the regulation of organisational, technological, and economic issues of forest management, considering their forestry, economic and social conditions, falls under the authority of 
the constituent entities of the Russian Federation.

According to the Concept Paper, control over forest management by state nature conservation and forestry organisations, as well as legal entities and individuals, shall be assigned to the executive agencies of the constituent entities of the Russian Federation and executive agencies of the Russian Federation within the areas corresponding to the distribution of authorities on forest management and use.

Powers to control the compliance with environmental requirements (environmental restrictions) in forestry, established by the laws of the Russian Federation, are provided by the federal executive agency exercising federal state environmental supervision.

\subsection{State forest policy}

The draft bill provides for the existence of a state forest policy in the Russian Federation, determined by the President of the Russian Federation. Forest policy should be part and parcel of the state social and economic policy aimed at the conservation and sustainable management of forests in order to best meet the needs of the society for forest products and services and to realise the rights of everyone for a favourable environment.

The goal of the state forest policy should be choosing a strategy for the development of the forest sector aimed at achieving and maintaining a balance of public interests with the creation of a favourable economic environment, as well as the preservation of the ecological value of forests and their social functions.

The adoption of the state forest policy should precede the formation and/or improvement of forest laws, strategic forest planning, as well as management decisionmaking in forest relations.

\subsection{Forest management}

Provisions of the Concept Paper are aimed at the formation of effective forest management mechanisms, corresponding to the intended purpose of forests and their economic zoning. They are based on the international experience of forest management, showing that in countries with a federal structure, the decentralised system of state forest management is most effective when the authorities for forest management and use are distributed on a territorial basis between the federal centre and the regions (constituent entities of the federation).

The Concept Paper proposes the distribution of authorities by levels of federal and regional management with indication of the main objectives of forest management (provision of timber, maintaining of employment, creation of favourable habitat, protection of natural ecosystems and conservation of biological diversity, maintenance of carbon balance, etc.). The specified forest management objectives shall become a priority for forest managers (organisations), and the area presented for the achievement of these goals shall not be given for other forest management objectives.

In the forests, the management of which is aimed at providing timber and maintaining of employment, other objectives of forest management should also be achieved, thus implementing the principles of multi-purpose forest use.

The Concept Paper provides for private forest management (conducting forestry). It is based on the same principles as those established for the management of state and municipal forests. 
Provisions of the Concept Paper determine the persons authorised to conduct forestry:

- in forests located on the lands of the forest fund, these are state and commercial forestry organisations;

- on lands of other categories, these are the forest owners.

The Concept Paper also establishes forest management units as follows:

- forest district is a territorial unit of state and economic management of forests;

- local forest district is an integral part of the territorial unit of forest management (forestry);

- forest quarter is an artificial unit of division of the local forest district into equal parts, marked in the area by natural or artificial boundaries (compartment lines) and boundary marks (compartment posts);

- taxation plot is a primary unit of forest inventory and assignment of forestry activities, characterised by homogeneous taxation characteristics and economic purposes;

- forest plot is a group of forest districts, forest quarters, taxation plots and their parts.

\subsubsection{Forest management authorities}

According to the Concept Paper, the Russian Federation and the constituent entities of the Russian Federation shall independently form a system of executive agencies in the field of forest management, based on their purpose and economic zoning, as well as forms of forest management.

According to the draft bill, the constituent entities of the Russian Federation shall form a system of state management of forests of protected areas of regional significance, protective and operational forests, whereas the
Russian Federation shall form that of forests of federal protected areas.

The Concept Paper also introduces restrictions on the functioning of forest management systems, including a ban on combining:

- state forest management with state forest oversight powers;

- regulation of forest relations with forest management powers;

- economic activity in forests (forest management) with the powers of the state forest protection centre, except for the powers to protect forests, first of all, from fires and illegal logging.

The draft bill expects that state management of protective and operational forests shall be carried out by specially authorised executive agencies of the constituent entities of the Russian Federation, and forestry here shall be conducted by state forestry organisations or legal entities and individuals who have concluded a license agreement for forestry in state forests.

To implement federal authorities in the field of forest management, the authorised agencies of state power of the Russian Federation shall establish specialised organisations to conduct state forest inventory, aviation protection, as well as monitoring of wilderness forests.

\subsubsection{State forestry organisations}

Laws shall cover forestry organisations established by agencies of state power of the constituent entities of the Russian Federation for the purpose of conducting forestry in operational and protective forests.

To ensure forest protection and conservation, the state forest protection centre is formed within the state forestry organisations, which has the rights to prevent, 
identify and suppress actions that cause damage to forests.

In accordance with the Concept Paper, state forestry organisations receive the right of ownership for timber and other forest resources produced by forestry operations. The sale of timber by state forestry organisations is carried out for round timber and (or) firewood, as well as through the issuance of short-term licenses for the procurement of timber to citizens and legal entities (selling standing timber).

Income from the sale of standing timber and other forest resources, as well as income from forestry services, arrives in the accounts of state forestry organisations and serves as the main source of funding for forestry. The disposal of the said financial resources shall be carried out in accordance with the business plan of the state forestry organisation, which is approved by the executive agency of the constituent entity of the Russian Federation authorised to manage forests.

State forestry organisations shall pay for the right of the permanent (termless) use of land plots from the forest fund, pay the valueadded tax when selling timber and other forest resources, and provide services of the forest economy.

To create a competitive environment, the Concept Paper places a ban on processing timber and other forest products by state forestry organisations.

State organisations for forest management of protected areas of federal significance shall be established by the federal executive agency, which shall carry out functions on the development of state policy and regulatory frameworks in the fields of study, use, reproduction and protection of natural resources.

\subsubsection{State forest guard}

To ensure the protection of forests against illegal activities, the Concept Paper provides for the establishment of the state forest protection centre within the agencies of state power of the constituent entities of the Russian Federation and state forestry organisations.

According to the Concept Paper, the objectives of the state forest protection centre as a part of a state power agency of the constituent entity of the Russian Federation include identification and suppression of violations of the forest law requirements by legal entities and individuals. For the realisation of the above objectives, they are granted the rights to initiate and carry out administrative proceedings, to issue to citizens and legal bodies within the limits of their competence directions (instructions) on elimination of violations and for decisionmaking on the suspension of economic activity in forests.

Officials of the state forest protection centre, formed as part of state forestry organisations, protect forests from illegal logging and prevent and extinguish forest fires. According to the Concept Paper, they are vested with the following rights:

- to check the citizens' and officials' documents permitting harvesting and transportation of forest resources;

- to draw up protocols (reports) on the violation of forest law;

- to send protocols on the violation of forest law to the relevant state authorities to bring forest poachers to disciplinary, administrative and criminal responsibility, as well as to compensate for the damage caused.

All officials of the state forest protection centre are allowed to store, carry and use 
service weapons in accordance with the procedure established by the laws of the Russian Federation.

To improve the efficiency of forest protection against illegal logging and forest fires, the Concept Paper provides for the granting of separate powers to forest managers under a license agreement or a forest trust management agreement to draw up protocols (records) on the violation of forest laws.

\subsubsection{State forest supervision}

State forest supervision means the systematic monitoring of forests, the identification of processes that impact forest ecosystems, the assessment of the impact of forestry activities, as well as the identification and suppression of violations by legal entities and individuals of requirements established by nature conservation (environmental) laws in relation to forests.

The main purpose of state forest supervision is to ensure control over compliance by executive agencies of the constituent entities of the Russian Federation, authorised to perform functions of state forest management, as well as by legal entities and individuals engaged in forestry operations, with nature conservation (environmental) restrictions established by the laws of the Russian Federation in order to preserve regulatory, environment forming, protective, including water protection, and other functions of forests.

According to the Concept Paper, state forest supervision is an integral part of the state environmental supervision and provided by the federal executive agency (its territorial bodies) that carries out federal state environmental supervision. The procedure for state forest supervision shall be established by the Government of the Russian Federation.

\subsubsection{Permanent (termless) use of forests}

The proposed forest management model expects the provision of land plots within protective and operational forests to state forestry organisations of the constituent entities of the Russian Federation for permanent (unlimited) use.

The decision to provide state forestry organisations with a land plot from protective and operational forests for permanent (unlimited) use shall be taken by the state agencies of the constituent entities of the Russian Federation.

Making decisions by executive agencies of the constituent entities of the Russian Federation on the provision of land plots from the forest fund to state forestry agencies for permanent (unlimited) use shall exercise the right of the forest owner to independently manage forests and receive income from such activities. With this decision, a constituent entity of the Russian Federation defines the form of providing forest resources on its territory for economic purposes, based on state participation in forestry activities and mechanisms of forest tenders and auctions for the sale of timber.

\subsubsection{Private (non-governmental) forest management}

As one of the forms of management of state forests, the Concept Paper proposes a model of private (non-governmental) management based on the transfer of rights and authorities related to the management of state forests to business entities for a period of more than 10 years.

For this purpose, a forestry license agreement shall be executed on a competitive 
basis with individuals and legal entities. Such an agreement shall be concluded in case the state agencies of a constituent entity of the Russian Federation decide on the inexpediency of forest management in state forests (or their part) by state forestry organisations.

According to the license agreement, the licensee shall ensure in the forests the performance of a set of forestry operations, including those related to timber harvesting, provided by the forest management plan, as well as the detection and extinguishing of forest fires.

State participation in this forest management model implies the protection of these forests from illegal activities, which shall be carried out by officials of territorial executive agencies of the constituent entities of the Russian Federation. Besides, territorial executive agencies of the constituent entities of the Russian Federation shall ensure control over compliance by the licensee with the requirements established for forest management, organise disaster response in forests associated with forest fires (other natural factors), as well as participate in planning and state support for forestry activities.

To conduct forestry in protective forests, the Concept Paper provides for the possibility of granting land plots within the forest fund to individuals and legal entities for trust management. The objectives of such management should be to maintain and develop regulatory, environment forming, protective, including water protection, sanitation and other functions of protective forests with their simultaneous use, provided that this use is compatible with the intended purpose of protective forests and the protective functions they perform.

The decision on the granting of protective forests in trust management to private entrepreneurs or businesses is made by the executive agencies of the constituent entities of the Russian Federation if protective forests are located within the territories provided to legal entities and individuals under the license agreement for forestry management.

Management of forests growing on agricultural land and other lands owned by legal entities and individuals is ensured by the owners of these lands.

\subsection{Forestry}

One of the main innovations of the new Forest Code should be the legal definition of forestry as a sector of economy, which addresses the sustainable use and conservation of forests as an essential component of the biosphere for the benefit of present and future generations.

According to the Concept Paper, forestry activity $\mathrm{i}$ becomes a type of economic activity associated with the cultivation of highly productive forest stands of target species on the forest land, as well as meeting the needs of the society for the environment-forming, regulating, protective, including water protection, cultural and other services of forests.

At the same time, the Concept Paper restores and implements the traditional understanding of forestry as a form of forest use, which, in operational forests, include:

(a) in areas of intensive forestry - forest engineering, timber harvesting, forest protection and conservation, selection and genetic activities, seed harvesting, reforestation and care of stands; 
(b) in areas of extensive forest use inventory of mature and overmature forests, planning (placement) of felling areas, felling of damaged, mature and overmature stands, protection of forests from fires, protection of young growth and promotion of natural regeneration of economically valuable species.

In protective forests, forestry aims to maintain the regulating, supporting, environment forming, protective and other ecosystem functions and services of forests with their simultaneous use, provided that this use is compatible with the intended purpose of protective forests and the functions they perform. It is considered a type of economic non-commercial activity to protect forests and to preserve (strengthen) their protective potential and ecological functions.

The draft bill also includes harvesting of food and other non-wood forest products, providing the society with ecosystem services of forests, including recreation, as part of conducting forestry in operational and protective forests.

Forest management in forests of specially protected natural areas (SPNA, that is, natural reserves, national parks, etc.) is defined as a conservation activity which aims to preserve forest ecosystems and forest biological diversity. The legal regime in the forests of these areas is established by the laws of the Russian Federation on protected areas. The use of forests within water protection areas is restricted by water laws.

Forestry in wildlife forests, according to the Concept Paper, is limited to extinguishing forest fires that threaten human settlements, economic objects and especially valuable forest areas, as well as their periodic inventory to identify and assess the impacts of anthropogenic and natural factors on forest ecosystems.

The Concept Paper also provides for the possibility of forestry on agricultural land that has been excluded from agricultural turnover, and reserved lands. The objectives of such management include forest farming, agroforestry, plantation forestry, as well as the restoration of forest ecosystems and landscapes to create a favourable environment or to improve the climate regulation capacity of forests.

It is proposed to transfer forestry activity in state forests to state forestry organisations and the organisation of the long-term provision of forest services and products (including timber), as well as the implementation of investment projects implemented in the forest sector to individuals using forests. The Concept Paper specifies conditions and procedures for such use of forests.

To eliminate unreasonable costs and to improve the efficiency of forestry, the Concept Paper prioritises forest laws in the regulation of forest relations while addressing tasks related to forest management.

\subsubsection{Logging for the purpose of timber providing}

In accordance with the main provisions of the Concept Paper, timber harvesting is an integral part of forestry related to felling, skidding, cutting into lengths, storage and transportation from the forest. Along with the purpose of timber harvesting, the task of forest renewal is also being addressed during logging. Therefore, in the intensive forestry area, it is planned to widely use gradual, group selection and selection felling, which implies the gradual harvesting of mature stands and continuous forest use. 
The Concept Paper stipulates that timber shall be harvested in mature and overmature stands of operational and protective forests when maintaining the forest and during other loggings in the amount not exceeding the permitted felling area within each management section. The permitted felling area is defined separately for operational and protective forests and includes timber harvested for all types of fillings (including sanitation cutting).

Information obtained during the state forest inventory on the growth of forest stands located within the forest district or forest plot provided for forestry activity, considering losses from forest fires, pests and forest diseases, serves as a basis for the calculation of felling areas.

In case of emergency situations in the forest caused by fires, pests and diseases, or by weather conditions, resulting in the number of dead stands exceeding the established calculated felling area, by decision of the authorised executive agency of the constituent entity of the Russian Federation, it is allowed to increase the felling area and to recalculate the permissible wood withdrawal in the following years. Forests lost or damaged because of impact of these factors shall be used for timber harvesting in the first place unless otherwise stipulated by the current laws.

The estimated felling area is established by the decision of the authorised executive agency of the constituent entity of the Russian Federation for a forest district, as well as for each forest plot provided to a legal entity or individual for forestry or under a contract of trust management. The procedure for defining permitted felling areas for forest districts, as well as for forest plots provided for long-term use, is established by the Government of the Russian Federation.

The Concept Paper also establishes forms, procedures and conditions of access to wood forest resources for citizens and legal entities. It is assumed that the economic needs for timber will be met both in the form of longterm provision of the forest plot for forestry (forest growing) and in the form of selling standing timber by state forestry organisations to legal entities and individuals.

It is assumed to supply the population with fuel wood and round wood for their own needs in the form of selling standing timber within the forest areas managed by the state forestry organisations. The population, to meet their own needs, shall also be granted the right to harvest, in accordance with the established procedure, the timber of dead trees (windfall trees and deadwood) in state forests, including those provided to legal entities and individuals for forestry.

The form of providing the population with wood resources within a constituent entity of the Russian Federation is defined by the law of the constituent entity of the Russian Federation concerning state woods located therein or their parts. The laws will also codify tools for providing forests for shortterm and long-term use.

It is assumed that in case of short-term forest use ( 1 to 5 years), the right to harvest timber will be granted based on a one-time license issued by the specialised state forestry organisation to an individual or legal entity for the specified volume of timber to be harvested. Such license shall be issued based on the results of bidding. The one-time harvesting license shall only be valid within a specific area, the boundaries of which are 
established at the time of license issue, and only for the volume of wood to be harvested.

Long-term harvesting of timber by individuals and legal entities for the purpose of raw material supply to wood-processing industries will be carried out based on a license agreement (license) for forestry in state forests. Along with the right to harvest timber, a person who is entering into such an agreement shall be obliged to detect and extinguish forest fires and to perform reforestation, forest care and other forestry activities, the contents of which are determined by the forest management plan at the respective forest plot.

The license agreement for forestry in state forests is concluded with an authorised state (executive) agency of the constituent entity of the Russian Federation and provides for the transfer to the licensee of rights to forestry in state forests for the period from 10 to 49 years.

The compulsory conditions of such license agreement include requirements to conduct a periodic evaluation of the licensee's activity (every 5 years) with subsequent extension of the license if the results of such evaluation are considered satisfactory.

The license agreement for conducting forestry in operational forests is limited to a certain territory, the boundaries of which are established at the agreement conclusion.

The long-term right of legal entities and individuals to harvest timber in protective forests owned by state may arise solely on the basis of a contract of trust management for such forests. In this case, felling parameters for protective forests and rules for timber harvesting in such forests are established by the Government of the Russian Federation. Felling parameters for operational forests and rules of timber harvesting in such forests are established by the state agencies of the constituent entity of the Russian Federation.

The volume of timber allowed for harvesting, its assortment and quality are determined during felling area allocation. According to the Concept Paper, the felling area shall be allotted by the forest user under the control of the forest management bodies of the constituent entity of the Russian Federation (selective control over the allotment quality is provided).

In forests located within the areas of extensive forest use, the volume of wood to be harvested and tree species and assortment are determined by the area and materials of the inventory of mature and overmature forest stands.

\subsubsection{Meeting the need of the forest industries for timber}

The draft bill establishes the requirements and restrictions aimed at the development of domestic wood processing through the development of a long-term market for round (unprocessed) timber and materials sold as standing timber in the Russian Federation. The basis of the proposed innovations are the regulatory requirements to the state forestry institutions for competitive sale of round and standing timber. Moreover, to create a competitive environment in timber processing, the Concept Paper prohibits state forestry organisations from processing timber.

For persons harvesting timber under a long-term forestry license, there are restrictions on the export of round wood intended for processing by sawing, peeling or slicing. The Concept Paper also provides for the initiation of restrictive measures for the export of primary processing timber. 
To provide raw material resources for timber processing enterprises, the Concept Paper gives the executive agencies of the constituent entities of the Russian Federation, as well as state forestry organisations under their jurisdiction, the right to hold closed tenders for the supply of timber (both in the form of round and standing timber), with limited participation of persons engaged in timber processing. According to the results of such tenders, the winners are granted onetime harvesting licenses for up to 1 year, or futures contracts for round wood purchase or the provision of felling areas for up to 5 years at the current market price.

Persons harvesting timber based on the license agreement for forestry in state forests shall dispose of harvested timber at their own discretion, except for the export of raw timber and primary processing materials.

To develop the forest industry and to provide sustainable supplies of raw materials to domestic manufacturers of wood boards, pulp, paper, wood fibres and other products of added-value wood processing, the Concept Paper provides for the development of plantation forestry to obtain wood of the target species and specific assortiment.

To establish forest plantations and their exploitation, the Concept Paper provides for the purchase and sale of a land plot from operational forests in state ownership. At the same time, the Concept Paper prohibits the turnover of land plots for other purposes, as well as the turnover of land plots located in the forests of SPNA, protective forests and wilderness forests.

\subsubsection{Standing and fallen deadwood harvesting}

The Concept Paper proposes norms for harvesting in the forest:
- $\quad$ of fallen deadwood, i.e. trees lying on the ground in the forest that have lost the quality of freshly-cut wood, formed because of impact of wind, snow, ice and other natural phenomena, as well as trees that have fallen because of natural death due to senescence;

- of standing dead trees, i.e. trees that are dead and dried up but are standing.

According to the Concept Paper, fallen deadwood harvesting can be carried out by citizens to meet their own needs in fuel wood as well as by legal entities and individuals for business activities.

Deadwood harvesting by citizens to meet their own needs in fuel wood is carried out freely in forests and with restrictions in protective forests. To ensure control over forest protection during deadwood harvesting by citizens, the state has the right to establish days of the week or calendar time of the year when this activity is allowed.

Legal entities and individuals shall carry out fallen deadwood and standing dead trees harvesting in the course of entrepreneurial activities on the basis of a license (permission) for this type of activity, issued by a specially authorised executive agency of a constituent entity of the Russian Federation or a state forestry organisation for a certain period of time, within a certain forest area.

The rules of fallen deadwood and standing dead trees harvesting by citizens and legal entities for the purpose of their business activities, the procedure for issuing the relevant license (permission), the procedure for the accounting of harvested wood and the amount of payment for it shall be established by the agency of state power of the constituent entity of the Russian Federation. 


\subsubsection{Commercial harvesting and} picking up the non-wood forest products

Citizens and legal entities using forests for the purpose of entrepreneurial activity shall harvest and collect non-wood forest products accordingly permission for forest land plot usage issued by the state forestry organisations for a certain time within a certain forest area.

The rules for harvesting and collecting non-wood forest resources by citizens and legal entities for the purpose of their business activities, the procedure for obtaining a permission for forest land plot usage, the accounting for harvested products and the amount of payment for it shall be established by the agency of state power of the constituent entity of the Russian Federation.

\subsubsection{Ecosystem services of forests}

One of the innovations of the Concept Paper is the legislative definition of the ecosystem services of forests, their measurability and value. Forest laws are expected to have mechanisms for the monetary estimates of not only providing, but also supporting, regulating and cultural ecosystem services of forests, as well as the economic forms of their provision.

The Concept Paper provides a legal framework for the creation and development of a market for ecosystem services and identifies its users and beneficiaries. The protection of protective forests and, specially protected forest plots, carried out by state forestry organisations, as well as private entrepreneurial structures under trust management of forests, is a form of providing services to the society in the field of forestry.

If wood or other products are produced owing forest management by persons taken protective forests in trust, they belong to the forest manager and their cost is considered when assessing the remuneration for trust management.

\subsubsection{Use of forests for non-forestry purposes}

The Concept Paper provides for granting the right of the limited use of a forest plot for non-forestry purposes by establishing servitudes to land plots located within the lands of forest fund. Encumbrance on a forest plot in the form of servitude or public servitude does not deprive the forest owner of the right to own, use and dispose of the forests.

Public servitude for using land plots within the lands of the forest fund shall be established with the following objectives:

- to accommodate power grid facilities, heat networks, water supply networks, water disposal networks, communication lines and facilities, linear facilities of gas supply system, oil pipelines and oil products pipelines, as well as their integral technological parts;

- to accommodate highways and railroad tracks;

- to carry out geological exploration and mining;

- to carry out research and development work, for educational purposes, and to house permanent experimental facilities.

In accordance with the Concept Paper, public servitude is established:

- in operational and protective forests - by decisions of the authorised executive agencies of state power of the constituent entities of the Russian Federation;

- in the SPNA forests (if such activities are permitted by protected area regimes) and 
wilderness forests - by decisions of the authorised federal executive agencies.

In cases of placement of engineering structures of federal importance, public servitude is established by the authorised federal executive agency for all categories of forests.

Persons in whose interest servitude (public servitude) is established shall pay a fee for the use of the forest plot to the Russian Federation budget. The Government of the Russian Federation shall establish the amount and procedure of payment.

The fee for servitude is not established for research and educational institutions that use forests for the purposes of research work and the placement of permanent experimental facilities.

In cases when the establishment of servitude requires the felling of tree stands (considering the legal regime of protective forests and the regime of SPNA), the applicant shall purchase standing timber within the requested land plot.

\subsubsection{Protection and conservation of forests}

Forests shall be protected from fires, pests and forest diseases, as well as from illegal activities that cause damage to forests and forestry.

According to the Concept Paper, protection and conservation of forests, except for measures aimed at prevention, identification and suppression of violations of forest and nature conservation laws of the Russian Federation, are provided by state forestry organisations and by legal entities and individuals engaged in forestry on the basis of a license agreement and a contract of trust management of protective forests.
The protection of forests from illegal (criminal) encroachments that cause damage to forest stands, including forests provided to business structures under a forestry license agreement or a trust management agreement, is carried out by the authorised executive agencies of the constituent entities of the Russian Federation.

Adoption of the draft bill will ensure a more effective solution of tasks on forest protection and conservation, including:

- forest fire protection;

- forest protection from pests and diseases;

- identification and suppression of violations of norms and rules established by the state for effective forestry;

- forest protection from illegal activities (including illegal felling).

Forest fire protection provides for ensuring fire safety measures in forests, forest fire detection and extinguishing. In forests provided to legal entities and individuals for forestry accordingly the license agreement and the contract of trust management of protective forests, forest fire protection is carried out by mention above legal entities and individuals. Costs incurred by legal entities and individuals during extinguishing forest fires shall be reimbursed from the budgets of the constituent entities of the Russian Federation and in case of emergency response from the reserve fund of the Government of the Russian Federation.

The range and scope of measures to protect and conserve forests shall be determined by the forest management plan (forest inventory). In accordance with the Concept Paper, failure to implement the forest management plan is the reason for the early termination of the contract of trust management by protective forests, revocation 
of the license for forest management in operational forests and termination of the right of the permanent (unlimited) use of forests.

To extinguish forest fires, agencies of state power of the constituent entities of the Russian Federation shall have the right to engage state and municipal fire departments, fire-fighting units of legal entities and members of the voluntary fire guard.

In case of an emergency in the forests due to forest fires, emergency recovery shall be performed by the Russian Federation Ministry of Civil Defense and Emergency Response and its territorial subdivisions. The procedure for imposing the state of emergency in forests, including evaluation criteria for its imposition, considering the area of forest fires, threat to social and economic objects, shall be established by the Government of the Russian Federation.

In remote operational and protective forests where ground extinguishing of forest fires is impossible due to their transport inaccessibility, forest fires shall be extinguished by a specialised forest aviation protection established by the authorised executive agency of the Russian Federation. Aviation protection is also responsible for extinguishing forest fires in wilderness forests that threaten human settlements, engineering structures and particularly valuable forest areas.

Forest aviation protection is a set of measures aimed at the early detection and extinguishing of forest fires using aircrafts. Assignment of forest areas to the aviation protection zones and the procedure for protection implementation shall be established by the Government of the Russian Federation. The use of aircrafts to detect forest fires in the ground protection zone of forests is part of the measures to detect forest fires and is carried out by the constituent entities of the Russian Federation independently.

Forest protection is aimed at identifying individual trees and stands damaged by pests and diseases, preventing their spread and minimising economic damage to forests caused by pests. To ensure sanitary safety in operational and protective forests, ground and aviation operations are carried out, including forest health monitoring, containment and elimination of pest outbreaks, including sanitation cutting.

If within the forest districts, as well as forest plots, there are stands damaged by forest pests and diseases whose timber is suitable for economic use felling of healthy stands is not allowed. Merchantable wood harvested during sanitation cutting is included in the calculated felling area.

Within the specially protected forest plots and the SPNA, sanitation cutting is carried out only for the purpose of eliminating the threat of emergency situations related to the spread of pests and diseases of the forest, as well as for the purpose of emergency recovery. No measures shall be taken to protect wilderness forests.

The Concept Paper prohibits forest health inspections and sanitation measures by organisations carrying out state forest health monitoring and state forest inventory.

\subsubsection{Conservation of forest biological diversity and genetic resources}

Forest biological diversity and genetic resources are conserved to ensure sustainable forest management, balanced ecosystem 
services of forests and forest conservation for future generations.

The Concept Paper defines that the conservation of forest biological diversity in operational forests is carried out through the designation of special protective forest areas, including:

- protected forest plots;

- habitats of rare and endangered fauna and flora species;

- key biotopes and protected areas.

Allocation of special protective forest plots within exploitable forests is carried out by decisions of the authorised executive agencies of the constituent entities of the Russian Federation in accordance with the forest and nature conservation laws.

In the SPNA forests, protective forests and wilderness forests, conservation of biological diversity is one of the main objectives of forest management.

Rare and threatened species of flora and fauna, listed in the Red Book of the Russian Federation or the Red Books of the constituent entities of the Russian Federation, shall be protected in accordance with the laws on environmental protection.

Forest genetic resources are conserved by maintaining the genetic diversity of woody plants:

- in natural habitats, this includes the identification of forest genetic reserves, the creation of other special objects (special protective forest areas, key biotopes, etc.) and the improvement of forest exploitation and reforestation technologies;

- outside natural habitats, it involves the creation of objects of a unified genetic breeding pool (UGBP) for the purpose of conservation of the most valuable genotypes and populations of forest plants and the creation of genetic banks of seeds, pollen grains and meristems.

\subsubsection{Selection seed breeding and harvesting of forest tree seeds}

The Concept Paper defines forest selection seed breeding as one of the main areas of forestry activities, whose task is to produce seeds of forest plants with valuable (improved) hereditary properties. It includes a set of measures on the creation and allocation of objects of a permanent forest-seed establishment, including seed plantations, superior trees and stands. Forest selection seed breeding is carried out by state forestry organisations. The Concept Paper prohibits artificial reforestation using seeds collected from random trees if there are seeds with improved hereditary properties.

Harvesting of forest plant seeds at felling sites and from growing trees outside seed plantations is not a part of forest selection seed breeding, and it is carried out by legal entities and individuals providing services of trust management by protective forests, as well as managed by operational forests under the license agreement. Moreover, the right to the free harvesting of forest plant seeds is also granted to citizens engaged in seed collection entrepreneurial activities if it is not associated with logging and damage to forest stands.

In accordance with the Concept Paper, forest seed zoning shall be carried out by the authorised federal executive agency.

\subsubsection{Reforestation}

Reforestation is carried out by means of natural and artificial regeneration of forests and by a combination of these methods, depending on the presence of economically 
valuable undergrowth at felling and burnt (forest fires) sites.

The Concept Paper considers forest sowing and planting within felling sites and within forest lands with dead trees as artificial reforestation. It is used to enhance the productivity of forests and to reduce the felling interval of forest stands, primarily using seed (planting) material with improved hereditary properties.

In the area of intensive forestry of operational forests, artificial reforestation is mandatory in case of impossibility to provide natural reforestation in the felling sites with the target species, as well as at the felling sites and areas where the undergrowth of economically valuable species has been destroyed.

Artificial forest regeneration is ensured by sowing and planting of woody plants in protective and operational forests after clear cutting or death of stands. Artificially created forests include stands with a share of forest plantations of $50 \%$ or more.

The Concept Paper includes the cultivation of planting material, i.e. seedlings and saplings of the main forest-forming species, as part of reforestation measures. Cultivation of planting material is carried out by persons engaged in forestry on the lands of the forest fund without provision of a land plot. Upon completion of the use of forest land for these purposes, it shall be restored (reforestation).

Artificial reforestation activities also include agrotechnical tending of artificially regenerated stands and thinning of young trees. Successful artificial regeneration of forests results in the transfer of forest plantations to the land occupied by forest stands, carried out after elimination of the competition of undesirable softwood undergrowth.

Natural regeneration of forests is used as the main method of reforestation after felling operational forests in the areas of extensive forestry. In the areas of intensive forestry, natural reforestation is carried out if the preserved undergrowth is of the target species, cultivation of which is the purpose of forestry determined by forest engineering.

The following activities are implemented to promote natural reforestation:

- preservation of a viable generation of target tree species renewed under the canopy of forest stands;

- soil scarification at the sites of planned cutting of mature and overmature stands and at cutting sites;

- leaving seed trees, tree bunches and groups.

During gradual felling, the formation of natural regrowth and undergrowth of economically valuable species is carried out throughout the whole felling period and ends by the time of its final stage.

The Concept Paper provides for the responsibility of persons engaged in forestry activity accordingly a license agreement or a trust management agreement for the preservation of economically valuable undergrowth during the felling of forest stands. In case of death of economically valuable undergrowth species as a result of unsatisfactory felling, reforestation measures shall be carried out at the expense of the forest user.

A fundamental proposition of the Concept Paper is the abandonment of the legal regulation of technological issues in reforestation. According to Concept Paper, only those areas of public importance that 
ensure the conservation of the supporting, regulating, protective and environment forming functions of forests, as well as their multifunctional and sustainable management, are subject to regulation.

This approach will make it possible to ensure the introduction of management mechanisms in forestry aimed at creating economic incentives for the reproduction of forests with economically valuable species, increasing the productivity and quality of forest stands.

Besides, the elimination of excessive legal requirements for the reforestation process will promote the use of new knowledge and domestic and foreign technologies, facilitating profitable forestry and eliminating the need for additional state funding.

\subsubsection{Thinning}

The Concept Paper assumes that thinning shall be carried out in the intensive forestry areas allocated within operational forests, as well as in the protective forests where timber harvesting is allowed. Thinning can also be carried out during the restoration of ecosystems of protective forests and the SPNA forests.

In operational forests, the objectives of thinning should be:

- prevention of the change of the main tree species;

- increasing the productivity of tree stands and improving the quality of the timber being formed;

- obtaining additional income from the sale of timber harvested when tending for forests.

In protective forests, thinning is aimed at the preservation and strengthening of supporting, regulating, environment-forming, and protective, including water protection functions.
The assignment and implementation of thinning in young forests with economically valuable species are prerequisites for planning and management in the forest. Thinnings to increase the productivity of the tree stands and to improve their quality are carried out if there are funds for and if there are markets for the harvested timber.

In the forests of protected areas and wilderness forests, thinning is carried out if its implementation meets the objectives of the formation and conditions of sustainable functioning of the protected area.

In case of extensive forestry areas, no thinning is conducted in operational forests.

\subsection{Forest arrangement}

Forest arrangement includes a system of measures aimed at ensuring sustainable and effective forestry. Forest arrangement includes:

- delimitation of protective and operational forests, wilderness forests, protected forest areas, forest districts, forest quarters, taxation plots and forest plots;

- forest taxation, i.e. determining their quantitative and qualitative characteristics by ground - based and remote sensing methods;

- drawing up a forest management plan, which is a reasonable prescription of measures for the use, protection, conservation and regeneration of forests.

The Concept Paper sets forth mandatory conditions that provide for the periodic implementation of a set of forest arrangement activities in the SPNA forest, protective and operational forests.

In the forests of the specified purpose, forest arrangement (inventory) contains a description of forest boundaries, data on forest stand taxation, as well as a plan of forestry therein. During forest arrangement, 
taxation plots (areas) are allocated, target species and reforestation methods are selected, cutting age, permitted felling volume, felling intensity and sequence are determined, and economically substantiated economic instructions on forest care are given.

In the area of extensive forestry of operational forests, forest arrangement is limited to the inventory of maturing, mature and overmature stands being involved in felling, felling planning, as well as measures to conserve economically valuable undergrowth and to promote natural forest regeneration.

No forest arrangement shall be carried out in wilderness forests.

Territorial units of forest arrangement are forest districts and forest plots provided to state forestry organisations for permanent (unlimited) use, as well as forest plots provided to legal entities and individuals for forestry accordingly a license agreement and (or) trust agreement.

According to the Concept Paper, forest arrangement is conducted by specialised state organisations as well as by legal entities and individuals listed in the state register of forest arrangement performers. Qualification requirements to persons carrying out forest arrangement activities as well as the procedure for keeping the state register of forest arrangement performers shall be established by the authorised federal executive agency.

The forest management plan drawn up during forest arrangement is aimed at achieving the management objectives defined by the forest owner (state) and serves as a guideline for forestry. The forest management plan contains forest taxation information on forest stands for each respective plot and a map base, representing the information basis for forest planning.

The forest management plan consists of a general and a private part. The general part of the plan serves to establish the future state of the forest to which forestry at the site should aspire. It includes:

- spatial organisation of forests with allocation of economically inaccessible areas and timber consumption zones;

- establishment of optimal forms of management and selection of wood species ensuring the highest permanent profitability of forests under existing natural and economic conditions;

- establishment of the best reforestation methods.

The private part of the forest management plan describes the methods of achieving the objectives defined by its general part. When drawing up this part, the spatial layout of felling is planned and the optimal felling interval is determined, considering the initial age structure of forest stands, and the necessary set of measures for the protection, conservation and regeneration of forests is determined.

The forest management plan for operational and protective forests under permanent (unlimited) use by state forestry organisations is developed on their order and approved by the authorised executive agency of the constituent entity of the Russian Federation. Within the boundaries defined by the license agreement for forestry and (or) the contract of trust management, the forest management plan is developed by order of the executive agency of the constituent entity of the Russian Federation. 
In protective forests and the SPNA forests, the main purpose of forest planning is to preserve forest ecosystems and to strengthen their supporting, regulating, environmentforming, water protection and other protective functions.

The forest management plan shall be developed for 5 years in intensive forestry areas and for 10 years in extensive forestry areas and shall be periodically reviewed in case of changes in the state of forests as well as when adjusting the objectives of the forest owner on forest management. Conducting forestry without a forest management plan is not allowed.

Establishing the boundaries of the taxation plot, forest quarter, forest plot during the forest arrangement is aimed at organising the economic management of forests and is carried out in accordance with the requirements established by the forest laws.

The boundaries of forests with adjacent land plots, the boundaries of forests provided for permanent (unlimited) use or trust management, as well as the boundaries of forest plots for which public (private) servitude is established for their use for purposes not related to forestry shall be determined in accordance with the land laws of the Russian Federation.

\subsection{National forest inventory}

In accordance with the Concept Paper, the Russian Federation shall ensure regular (every 5-10 years) national forest inventories (hereinafter referred to as NFIs). Such inventories are carried out within the framework of a unified system of state environmental monitoring (state monitoring of the environment) by the federal executive agency responsible for state management in the field of environmental protection.
The objectives of the NFIs are:

- assessment of the state of forests at the national and regional levels, the impact of forestry and other activities on forests;

- biodiversity assessment of forest ecosystems;

- assessment of ecosystem services provided by forests;

- identification of processes that have a negative impact on forests;

- information support for development of the national forest policy and improvement of the regulation of forest relations;

- implementation of international commitments on forests undertaken by the Russian Federation.

Information obtained during the NFI is also used to establish permissible norms of forest resources withdrawal, both for the Russian Federation as a whole and for its regions.

Within the framework of the NFI, it is planned to carry out forest health monitoring, the main task of which is to collect data on forest health to timely detect forest degradation and to predict the spread of pests in forests.

The NFI uses statistical methods of forest accounting based on data from the regular network of ground - based test plots and remote sensing data.

\subsection{Staying of citizens in forests}

The draft bill provides for the right of citizens to freely stay in forests and to harvest and collect, for their own needs, non-wood forest resources and fallen deadwood. These include bark of trees and shrubs, brushwood, forage, spruce, fir and pine branches, moss, forest litter and other similar resources, as 
well as fruits of wild plants, berries, nuts, mushrooms, seeds and birch sap.

In addition, the Concept Paper provides for the right of citizens to freely stay in the forest for the purpose of beekeeping for their own needs with the installation of beehives in the forest, which does not require tree felling or clearing (destruction) of forest cover.

The stay of citizens in state and municipal forests and the harvesting and collecting of non-wood forest resources by the population for their own needs can be limited in the SPNA forests, protective and operational forests and in wilderness forests in order to ensure fire and sanitary safety of forests, as well as during forestry operations that threaten the health of citizens.

In private forests, the forest owner may limit the building of bonfires, the installation of tents, as well as parking and other activities related to the use of forest plots during the stay of citizens in the forests.

\subsection{Capital construction and temporary facilities in forests}

The Concept Paper provides for the possibility to locate buildings and facilities in the forests, including capital construction, for the purpose of forestry. The construction of buildings and facilities, including those for forestry purposes, is not allowed in public forests (urban forests and forest park zones).

The construction of buildings and installations in the forests, provided for when granting the right of limited use of a forest plot for purposes not related to forestry by establishing servitudes, is allowed for the period for which a forest plot is given. After expiration of the terms set by the servitude (public servitude), these plots are subject to recultivation.
Facilities that improve the forest infrastructure shall be preserved. In this case when private forest management is terminated, the state as the owner of the forest shall compensate the forest user for the value of inseparable improvements made.

The construction of buildings and installations is limited in the SPNA forests, water protection zones, high conservation value forests as well as in other individual categories of protective forests, where the construction of facilities is unacceptable due to irreparable damage to forest ecosystems.

\subsection{Forest use fees}

The forest owner shall bear the burden of the costs for the protection, conservation and restoration of forests and is entitled to income from their use. The Concept Paper defines the conditions and procedure for the collection of payments for the unit of forest area provided for use as well as for the unit of the withdrawn forest resource.

It is assumed that payments for the use of forests for timber harvesting purposes will be made in the form of payments for roundwood, firewood and standing timber. The forest owner also receives one-time payments for the right to conclude a forestry license agreement, the amount of which is determined during public bidding.

The rates of payment for standing timber sold shall be established by the agency of state power of the constituent entity of the Russian Federation. According to the Concept Paper, they include the costs of forestry and are formed annually (for the forthcoming period) on the basis of the market price for forest resources, taking into account the results of public bidding for the sale of 
standing timber and tenders for the right to conclude a forestry license agreement.

The state forestry organisations of the constituent entities of the Russian Federation sell timber exclusively according to the results of forest tenders and (or) auctions. The form of bidding for the right to harvest timber shall be determined by the authorised executive agency of the constituent entity of the Russian Federation.

The Concept Paper defines that the payment for standing timber sold goes to the accounts of state forestry organisations for targeted use in forestry in accordance with the basic standard costs for the provision of services (performance of work) in the field of forestry, approved by a specially authorised executive agency of the constituent entity of the Russian Federation. If incomes of state forestry organisations from the sale of standing timber exceed the expenses provided for by the plans of their financial and business activities, the excess of income over expenses shall be directed to the corresponding budgets of the constituent entities of the Russian Federation.

It is also proposed to establish a procedure when persons engaged in timber harvesting accordingly a forestry license agreement in state forests, make payments for harvested standing timber. Payment for the right to conclude a forestry license agreement in state forests is charged once. The amount of such payments shall be determined as the sum of the rates of payment for the standing timber and the right to conclude a forestry license agreement based on the tender results.

Payments for sold standing timber from persons using forests accordingly the license agreement for forestry activities in state forests are transferred to the budgets of the constituent entities of the Russian Federation and serve as a source of recovery of the licensee's costs associated with the licensee for forestry.

The rates of payment for the use of nonwood forest resources shall be established by the agencies of state power of a constituent entity of the Russian Federation. The income for the use of non-wood forest resources goes to local (municipal) budgets.

The Concept Paper also establishes approaches to the valuation of forest ecosystem services based on the need:

- to improve the ecological potential of forests;

- to compensate for expenses related to the management of protective forests excluded from the economic turnover;

- to develop a market for ecological ecosystem services of forests, including climate and hydrological regime regulation, climate change mitigation, creation and retention of forest biota habitats, as well as recreational and other services.

\subsection{Forestry financing}

The objective of the federal law concept is to create conditions for economically efficient (profitable) forest management in state forests, transforming it into a sector of the economy that provides the society with forest products and services, satisfies the needs of the domestic forest industry for timber and creates and maintains a favourable environment.

The economic model underlying the Concept Paper assumes that forestry has its own income from timber sales as well as other forestry and ecosystem services.

In accordance with the proposed model, the constituent entities of the Russian 
Federation, which exercise authority to manage and use protective and operational forests, shall receive and manage the forest income, which they shall also use to provide protection, conservation and reproduction of forests on their territories.

When forestry activities are conducted by the state forestry organisations of the constituent entities of the Russian Federation, income from the implementation of forest services, including the sale of timber, income from the provision of forestry services belongs to these organisations and serves as a major source of funding for forestry activities.

When a license agreement for forestry operations in state forests is concluded with private business companies, the costs incurred by them for forestry operations (except for costs associated with the timber harvest) shall be reimbursed from the budget of the constituent entity of the Russian Federation in cash or by means of compensation when collecting payments for sold standing timber.

Federal income from joint possession of forests is supposed to consist of payments by the state forestry organisations of the constituent entities of the Russian Federation for the right of the permanent (unlimited) use of the land parcels as a part of forest fund, as well as the value-added tax from the sale of wood, other forest resources and forestry services.

The amount of the land tax for the rights of the permanent (unlimited) use of the land parcel within the forest fund is established by the Government of the Russian Federation based on the cadastral value of the forest fund lands.

The Concept Paper also provides for the preservation of the federal centre's income from the use of forests for purposes not related to forestry: construction and operation of linear structures, geological exploration, mining, etc.

These funds shall be transferred to the federal budget and serve as a source for the implementation of federal powers in relation to the state-owned forests, including aviation protection and national forest inventory.

In municipally or privately owned forests, the forest owner finances forestry.

\subsection{State support for forestry}

The Concept Paper assumes state support for forestry and forest infrastructure development in the following areas:

- forest zoning by category of ecosystem service;

- development of markets for forest ecosystem services;

- adaptation of forestry to climate change;

- forest seed production;

- ensuring measures to improve the fertility of forest soils;

- updating of the main equipment designed to detect and extinguish forest fires;

- ensuring the sustainable development of forest infrastructure, including construction and maintenance of forest roads;

- providing information on the state of forests, their quantitative and qualitative characteristics;

- forest planning;

- lending to timber producers (reimbursement of part of the loan interest charges);

- scientific and personnel support of forestry.

State support shall be provided to legal entities and individuals engaged in forestry activities on state- and privately-owned forest plots. 
Financing of state support of forestry is provided from federal and regional budgets.

\section{Transitional provisions}

The Concept Paper provides for the adoption of a special law on enactment of the new «Forest Code of the Russian Federation» in order to take into account all peculiarities of the new Forest Code implementation and to avoid loss of forest management sustainability and decrease of the forest complex efficiency. In accordance with the mentioned law, it is supposed to preserve the existing relations of the state with the persons using forests based on forest lease agreements until the moment of bringing the mentioned agreements in line with the new forest law.

To bring forest lease agreements in line with the draft bill, applications for the reexecution of such agreements in the form of forestry license agreements or agreements for trust management of protective forests for the period established earlier by the forest lease agreement shall be submitted.

In accordance with the Concept Paper, bringing the lease agreement of the forest fund plot in line with the new forest law is carried out within the period of validity of the forest management project prepared by the lessee for the types of forest use established by the forest lease agreement.

This approach to the implementation of the proposed legislative innovations allows to ensure the continuity of forest use by providing the lessees of the forest plots with the opportunity to operate forests without reexecuting the previously concluded forest area lease agreements until the implementation of the drawn-up forest development projects.
It is also assumed that the application of legal norms of the future law regulating issues related to the use of forests will be extended to persons using forests based on a forest land lease agreement only after their re-execution in the form of license agreements or trust management agreements. Before the constituent entities of the Russian Federation adopt relevant regional laws and regulatory acts, the Concept Paper provides for the maintenance of the legal force of laws and regulations adopted (issued) by the Government of the Russian Federation, federal executive agencies within the powers determined by the current «Forest Code of the Russian Federation».

To motivate legal entities and individuals to switch to the new forest management system, the Concept Paper provides for the possibility of early (before the end of the forest management project term) bringing previously concluded forest lease agreements into compliance with the new forest law. Such right is granted at the forest user's request.

\section{Place of future federal law in the system of current laws}

The «Forest Code of the Russian Federation» is a piece of law that acts as a system-forming (basic) act in the system of forest relations laws. The Code is aimed at the implementation of the provisions of the Constitution of the Russian Federation, establishing rights and obligations on the use and protection of natural resources and providing for the division of jurisdictions and powers between the agencies of state power of the Russian Federation and the agencies of state power of the constituent entities of the Russian Federation in matters of the 
possession, use and disposal of natural resources.

In case of adoption of the new «Forest Code of the Russian Federation», the «Forest Code of the Russian Federation» No. 200-FZ, dated December 4, 2006, and Federal Law No. 201-FZ, dated December 4, 2006, On Enactment of the «Forest Code of the Russian Federation» shall be deemed invalid. Besides, for the purpose of ensuring communication and hierarchy of norms and the balance of the system of laws in the field of forest relations, certain legislative acts of the Russian Federation containing provisions regulating the field of forest relations, as well as legislative acts of the constituent entities of the Russian Federation in the relevant field, are subject to amendments.

The adoption of the Federal Law "Forest Code of the Russian Federation" will require that a number of by-laws adopted by the agencies of state power of the Russian Federation and the agencies of state power of the constituent entities of the Russian Federation to develop the «Forest Code of the Russian Federation» of 2006 be declared invalid.

\section{ACKNOWLEDGMENTS}

To develop the Concept, the research results of the RAS institutes were used within the framework of the project of the State Task of the CEPF RAS (AAAAA18-118052400130-7), the topic "Methodological approaches to the assessment of the structural organization and functioning of forest ecosystems"; the project "Decision - making Support for Forest Ecosystem Services in Europe Value Assessment, Synergy Effects and Trade - offs POLYFORES", which was announced the winner of the competition of the international initiative ERA NET SUMFOREST "SUSTAINABLE FORESTS FOR THE SOCIETY OF THE FUTURE"; the competition of the Ministry of Education and Science of the Russian Federation "Conducting research on priority areas with the participation of research organizations and universities of the EU member states in the framework of multilateral cooperation in the Horizon 2020 program for 2018-2020, including the ERA-NET initiatives (project identifier RFMEFI61618X0101); the project Spurring INnovations for Forest ECosystem SERvices in Europe "(SINCERE) of the winner of the RUR-05-2017 competition" Novel public policies, business models and mechanisms for the sustainable supply of and payment for forest ecosystem services "(HORIZON 2020). 